\title{
Soft tissue grafting to improve implant esthetics
}

This article was published in the following Dove Press journal:

Clinical, Cosmetic and Investigational Dentistry

16 September 2010

Number of times this article has been viewed

\section{Moawia M Kassab}

Division of Periodontics, Marquette University, School of Dentistry, Milwaukee, WI, USA
Correspondence: Moawia M Kassab Department of Surgical Sciences, Division of Periodontics, Marquette University, School of Dentistry, Milwaukee, WI 5320I, USA

Tel + I 4l4288 077|

Email moe.kassab@marquette.edu
Abstract: Dental implants are becoming the treatment of choice to replace missing teeth, especially if the adjacent teeth are free of restorations. When minimal bone width is present, implant placement becomes a challenge and often resulting in recession and dehiscence around the implant that leads to subsequent gingival recession. To correct such defect, the author turned to soft tissue autografting and allografting to correct a buccal dehiscence around tooth \#24 after a malpositioned implant placed by a different surgeon. A 25 -year-old woman presented with the chief complaint of gingival recession and exposure of implant threads around tooth \#24. The patient received three soft tissue grafting procedures to augment the gingival tissue. The first surgery included a connective tissue graft to increase the width of the keratinized gingival tissue. The second surgery included the use of autografting (connective tissue graft) to coronally position the soft tissue and achieve implant coverage. The third and final surgery included the use of allografting material Alloderm to increase and mask the implant from showing through the gingiva. Healing period was uneventful for the patient. After three surgical procedures, it appears that soft tissue grafting has increased the width and height of the gingiva surrounding the implant. The accomplished thickness of gingival tissue appeared to mask the showing of implant threads through the gingival tissue and allowed for achieving the desired esthetic that the patient desired. The aim of the study is to present a clinical case with soft tissue grafting procedures.

Keywords: case report, connective tissue, dental implants, allograft, coronally positioned flap

\section{Introduction}

The successful use of dental implants to replace missing teeth has been one of the most popular, exciting, and evolving areas of clinical dentistry. ${ }^{1}$ When implants are thought as a treatment option, treatment planning has become more complex for the dental practitioner, and an interdisciplinary team approach is recommended. ${ }^{2,3}$ Failure to demonstrate such an approach might lead to an undesirable implant complication as we saw in this case.

When planning for the placement of a single-tooth implant, there must be an adequate space between the crowns and roots (adequate bone height). Both the quantity and the quality of alveolar bone must be assessed before implant placement is considered. $^{4}$

Soft tissue grafting can be one of the treatment of choices to treat gingival recession and augment the keratinized gingiva. ${ }^{5,6}$ Autogenous and allografting material have been used to augment the gingival dimensions. ${ }^{7-10}$ The aim of this case report is to 
present a clinical case with soft tissue grafting procedures, including combining autogenous and allograft material to augment the gingival tissue.

\section{Case report}

A healthy 24-year-old woman presented with chief complaint of "my implant is showing through my gingival tissue". Patient was wondering if there is any periodontal treatment available to mask the showing of implant threads through the gingival tissue and prevent further recession. Tooth \#24 was congenitally missing. She presented with excellent oral hygiene, no history of periodontal disease, nonsmoker, and radiographic X-ray revealed normal bone morphology. Upon clinical examination, there was minimal buccal gingival thickness around the implant in site \#24. Her recent dental history included extraction of deciduous tooth $\# \mathrm{O}$, and an immediate implant (Astra Tech, London, UK; $3.5 \times 13 \mathrm{~mm}$ ) was placed in site $\# 24$. Her previous dental treatment was rendered by a different surgeon.

The patient presented to Marquette University Periodontal Clinic 4 months after implant placement. The implant appeared to be osseointegrated with a buccal dehiscence and $30 \%-40 \%$ of facial implant showing through gingival tissue due to minimal bone width (Figures 1A and 1B).

Since the implant was osseointegrated, removal of implant was not considered fearing damage to adjacent teeth when trephining the implant. Also, due to loss of buccal bone cortex, the positioning of implant outside the bony envelope and possible sloughing of fragile buccal gingival tissue-guided bone regeneration were not recommended. Faced with the esthetic concerns and possible future recession around that

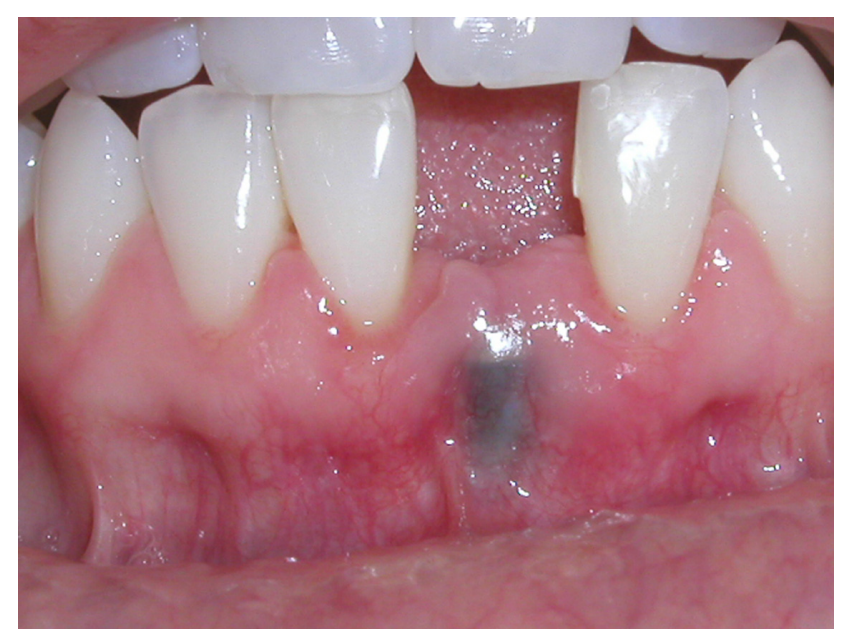

Figure IA Preoperative view showing malpositioned implant.

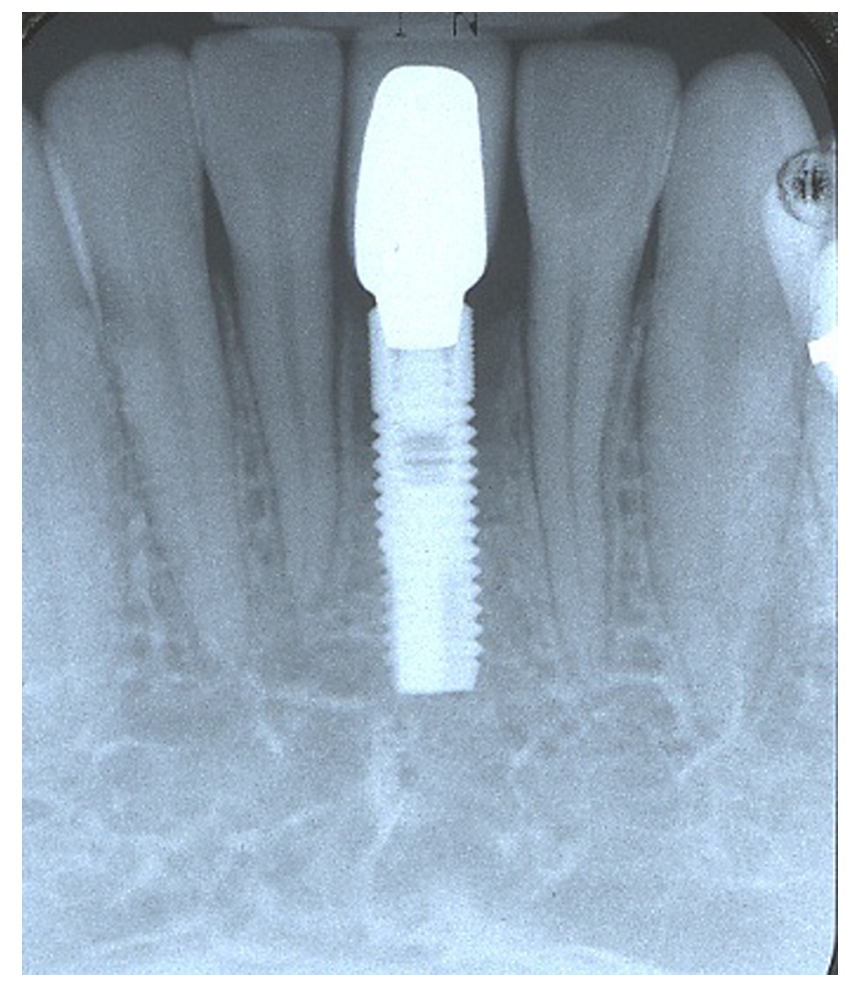

Figure IB Preoperative X-ray.

implant, soft tissue gingival grafting was recommended to augment the keratinized gingiva and improve esthetics.

\section{Surgery I}

The aim of the first surgery was to increase the zone of keratinized gingiva. The patient was anesthetized using $2 \%$ lidocain with 1:100,000 epinephrine followed by a partial thickness envelope flap including reflection of the papilla and extending the flap from tooth \#23 to \#25 and noticed buccal dehiscence and implant thread exposure $7 \mathrm{~mm}$ from

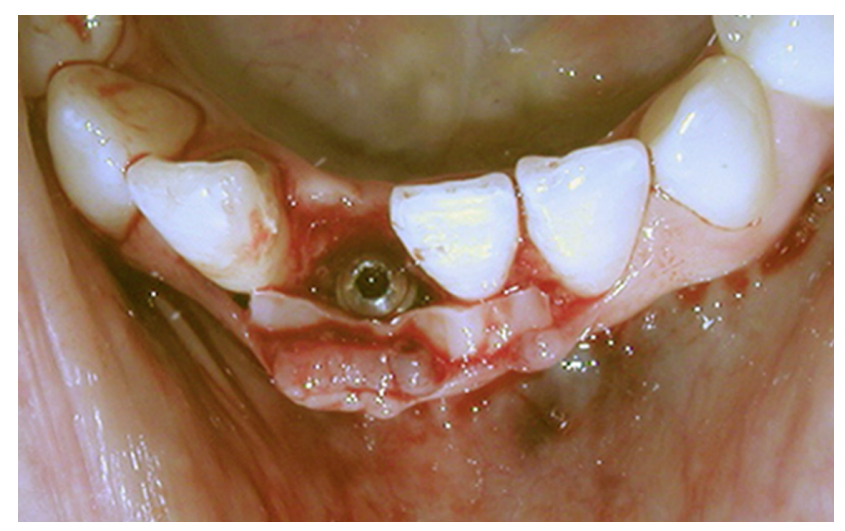

Figure IC Connective tissue graft in place. 


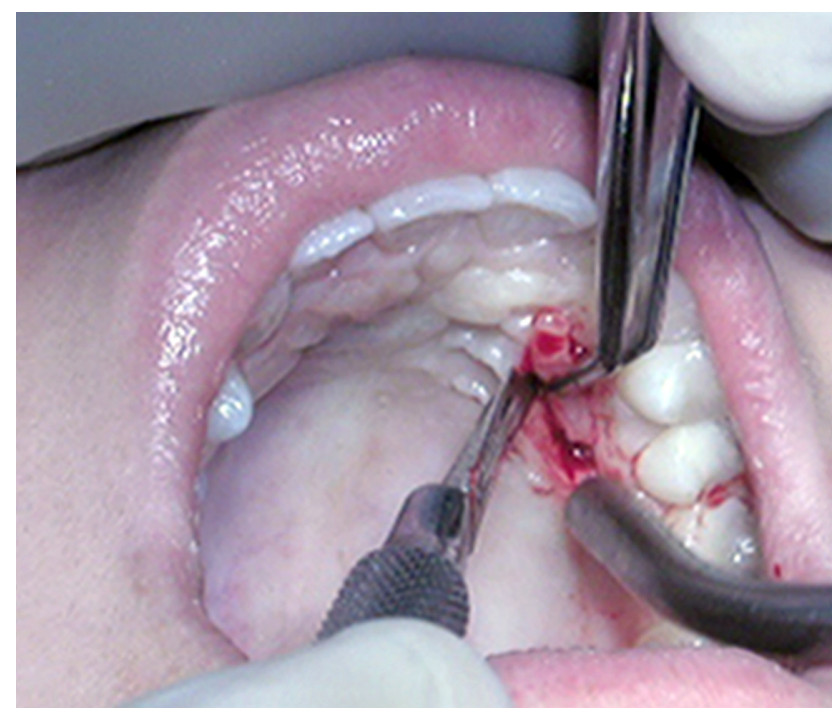

Figure ID Donor graft collected from unilateral palate.

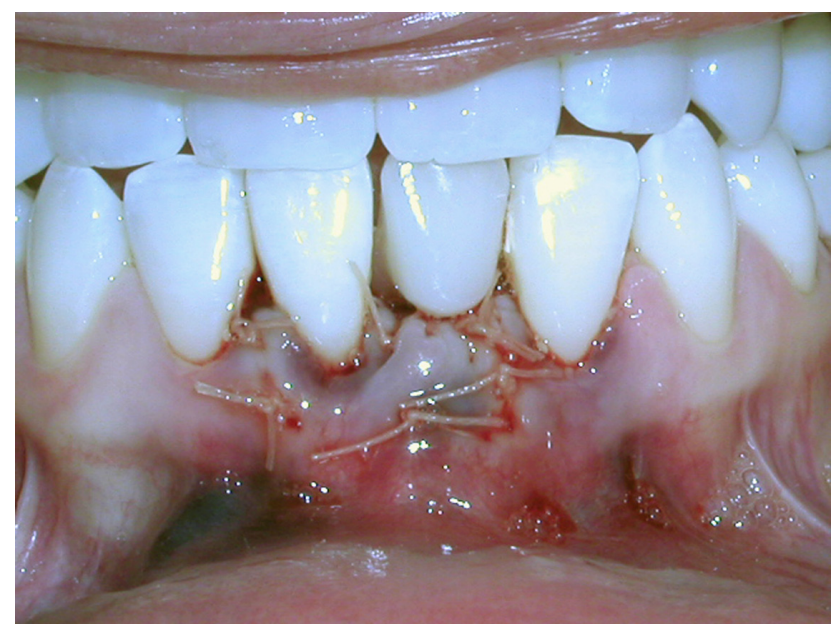

Figure IE Graft sutured in place.

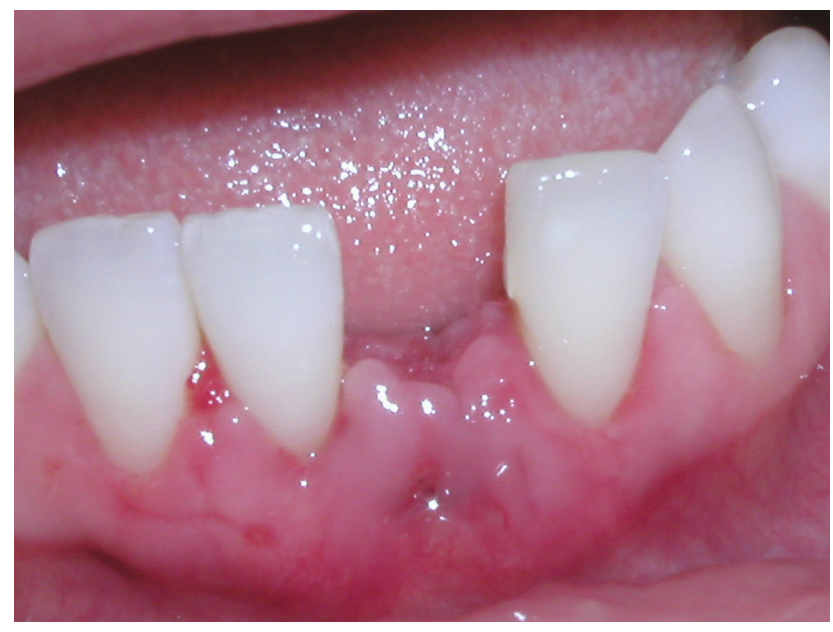

Figure IF 10 days postoperative.

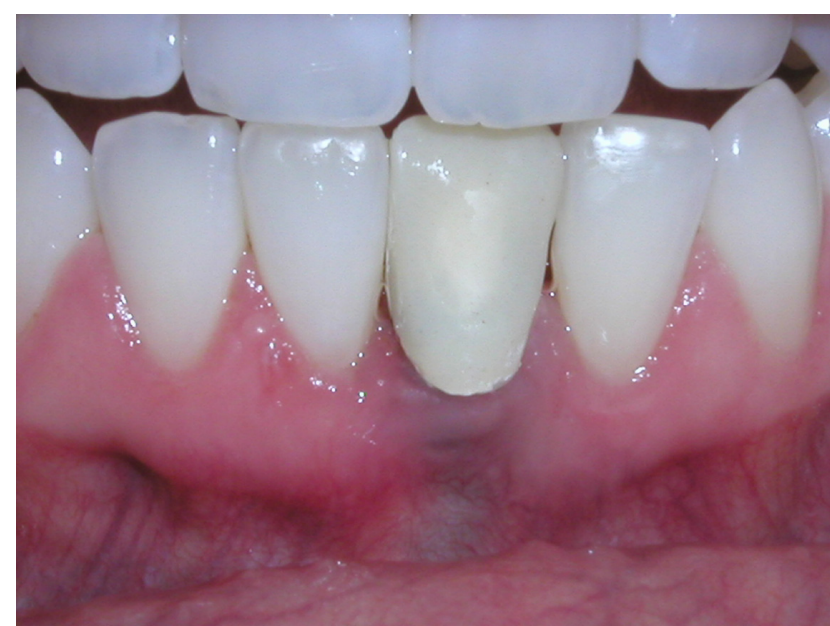

Figure IG 6 months postoperative.

implant platform coronally to osseous bone level apically. The donor connective tissue graft was collected from the palate (size $8 \times 12 \times 1.5 \mathrm{~mm}$ ); the graft was placed within the envelope flap (Figures $1 \mathrm{C}-1 \mathrm{G}$ ) and sutured in place using 5-0 Monocryl sutures. The flap was replaced and sutured using the same suture size and material. Healing was uneventful, and the patient was followed up for 6 months $(1,2,3,4,5$, 6 weeks and 3, 6 months) postoperatively, making sure to enforce oral hygiene and rinsing with chlorhexidine $0.12 \%$. At the 6-month reevaluation, it was determined that a second procedure was needed to mask the implant threads from showing through the gingival tissue.

\section{Surgery 2}

A subepithelial connective tissue graft was recommended to achieve gingival augmentation and to esthetically mask the appearance of the implant (see Figures $2 \mathrm{~A}-2 \mathrm{~F}$ ). The patient was anesthetized using 2\% lidocain with 1:100,000 epinephrine, and a partial-thickness supraperiosteal envelope flap was created without reflecting the papilla on mesial and distal of site \#24; ${ }^{11,12}$ the donor connective tissue graft was collected from the palate $(10 \times 12 \times 1.5 \mathrm{~mm})$. The graft was sutured in place using 5-0 Monocryl sutures, and the flap was coronally positioned and sutured using the same suture size and material. Healing was uneventful, and patient was followed up for 6 months $(1,2,3,4,5$, 6 weeks and 3, 6 months) postoperatively, making sure to enforce oral hygiene and rinsing with chlorhexidine $0.12 \%$. At the 9-month reevaluation, it was determined that a third procedure was needed to achieve implant coverage and augment the marginal tissue recession present. 


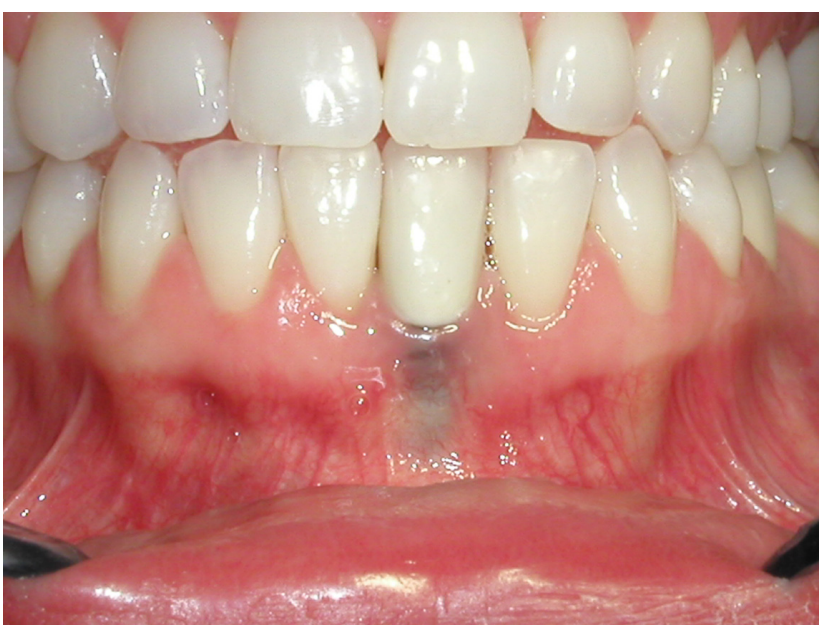

Figure 2A Second surgery preoperative.

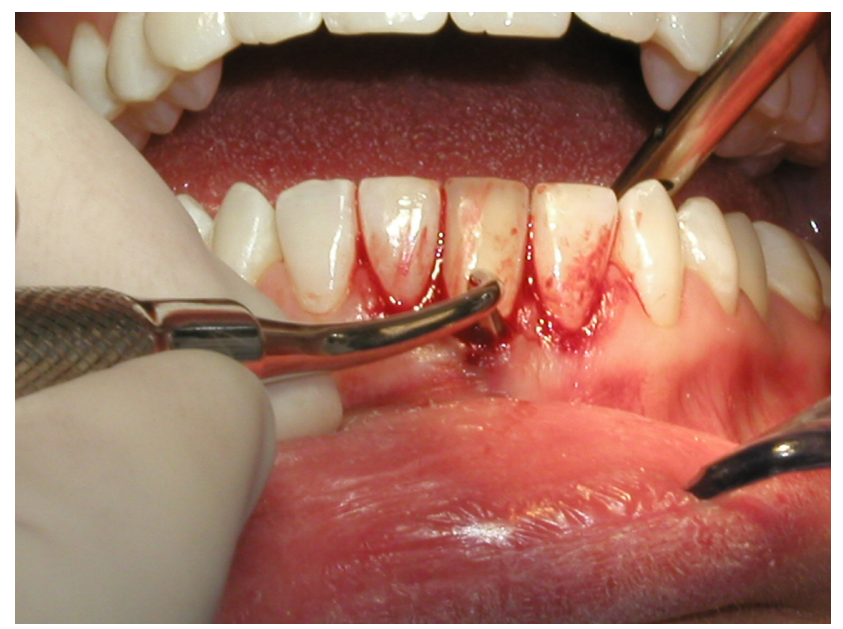

Figure 2B Partial thickness flap reflected keeping the papilla intact.

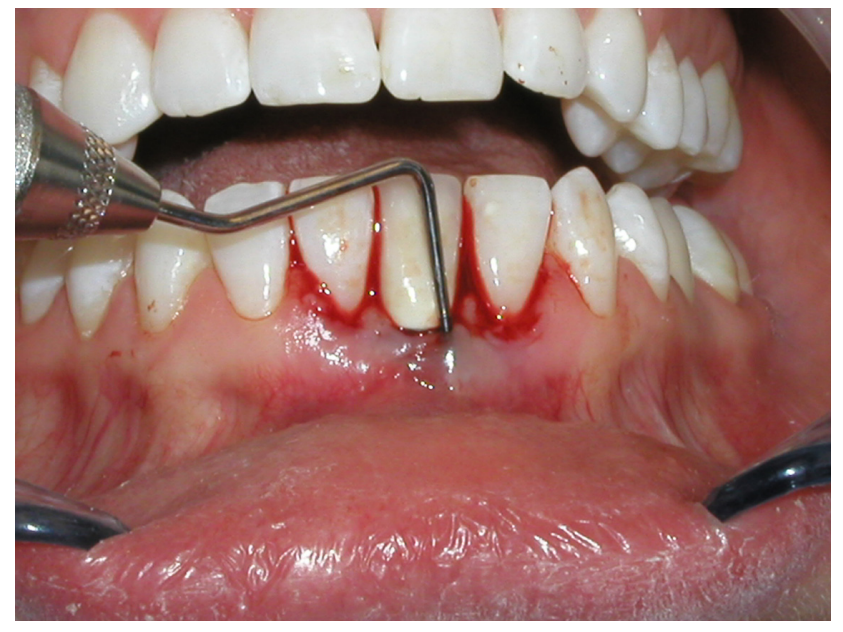

Figure 2C Partial thickness flap reflected beyond the mucogingival junction.

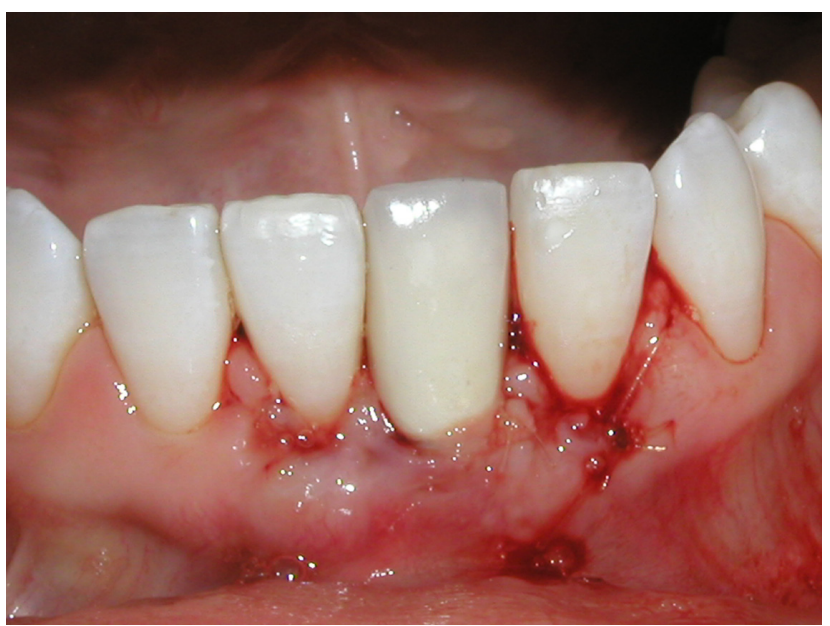

Figure 2D Suturing after surgery.

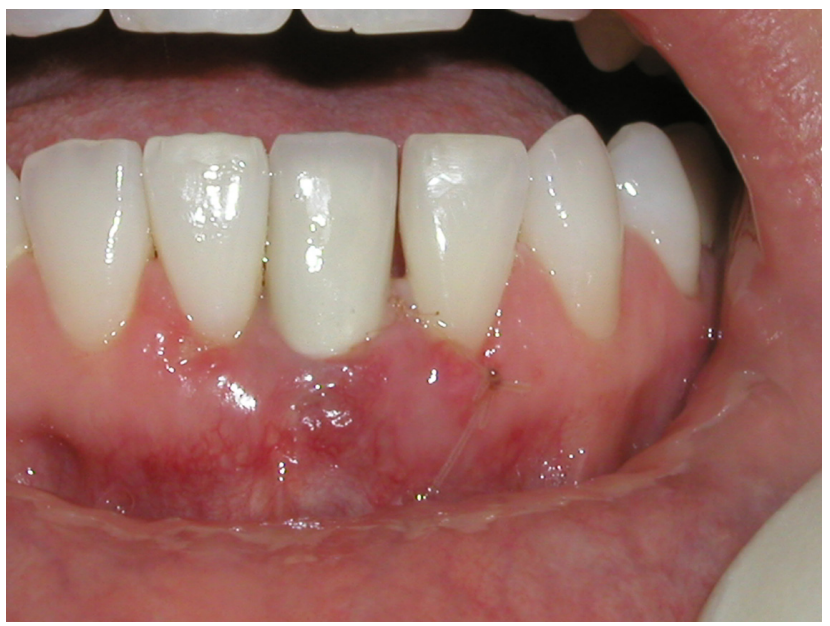

Figure 2E Two weeks postoperation.

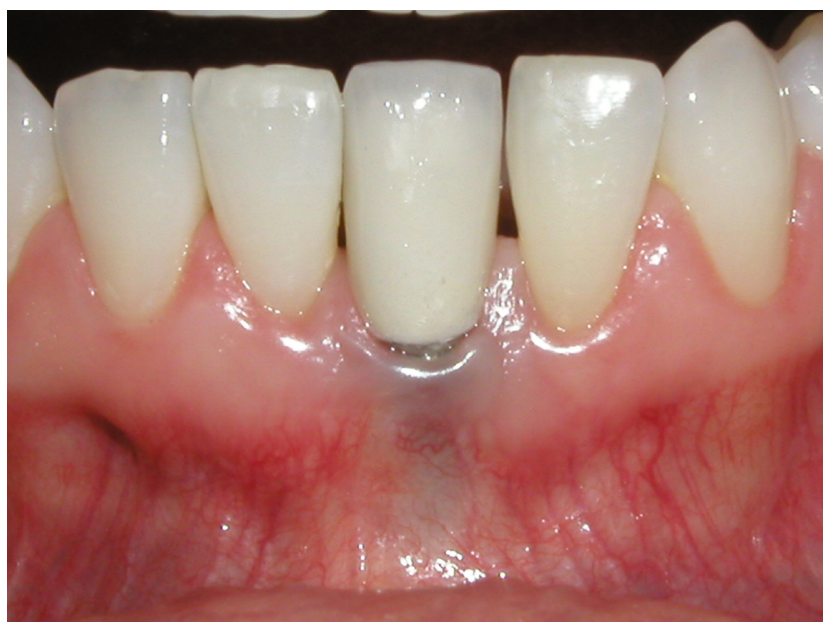

Figure $2 \mathrm{~F}$ Six months postoperation. 


\section{Surgery 3}

Soft tissue allograft Alloderm $^{\circledR}$; LifeCell Corporation, Palo Alto, CA) was recommended for this surgery. The patient was anesthetized using $2 \%$ lidocain with 1:100,000 epinephrine (Figures 3A-3F). In this surgical technique, the author elected to make a vertical incision mesial and distal to the implant site. A partial thickness flap was created on buccal \#24 without reflecting the papilla on the mesial and distal aspect. The Alloderm size chosen was $1 \times 2 \mathrm{~cm}$, and was hydrated according to the manufacturers' recommendation, then placed in the partial thickness flap covering the buccal aspect around the implant. After coronally positioning the flap, the Alloderm material was sutured in place using 6-0 monocryl sutures, and the incisions were sutured using the same material. Healing was uneventful, and patient was followed up for 6 months (1, 2, 3, 4, 5, 6 weeks and 3, 6 months) postoperatively, making sure to enforce oral hygiene. Chlorhexidine gluconate $0.12 \%$ mouth rinse was prescribed.

The patient was seen periodically for professional oral hygiene reinforcement and prophylaxis.

A 24-month evaluation revealed increase in gingival dimensions and achieving the desired esthetics.

\section{Discussion}

Although there were no promises made to the patient in term of achieving optimal esthetic results, she was informed of the need of multiple surgical procedures to obtain the desired results. We were facing two major problems with this case, first lack of keratinized gingival tissue to prevent further recession, and second lack of buccal bone to support soft tissue height. The average root coverage reported in the literature by Goldstein et a ${ }^{13}$ was $97 \%$ for intact roots and $92 \%$ for carious roots over a 34-month follow-up. Root coverage around dental implants depends on presence of bone to support the soft tissue. since we had at least $5 \mathrm{~mm}$ of bone dehiscence on buccal of the implant, there is certain limitation on the quantity of gingival augmentation even with multiple surgical procedures. In this case, we can attribute the success of soft tissue augmentation to the presence of healthy and normal height of interproximal bone mesial and distal to the implant site.

There were no randomized clinical trials favoring certain surgical procedure to cover implant dehiscence and augment keratinized gingiva. Short-term and long-term results of root coverage with connective tissue grafts on intact roots tended to improve with time ("creeping reattachment" as

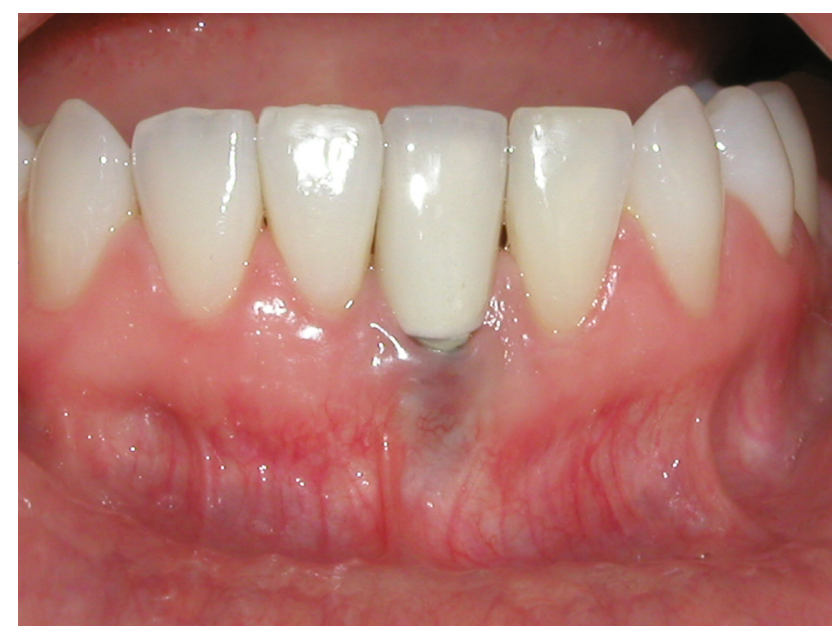

Figure 3A Third surgery preoperative.

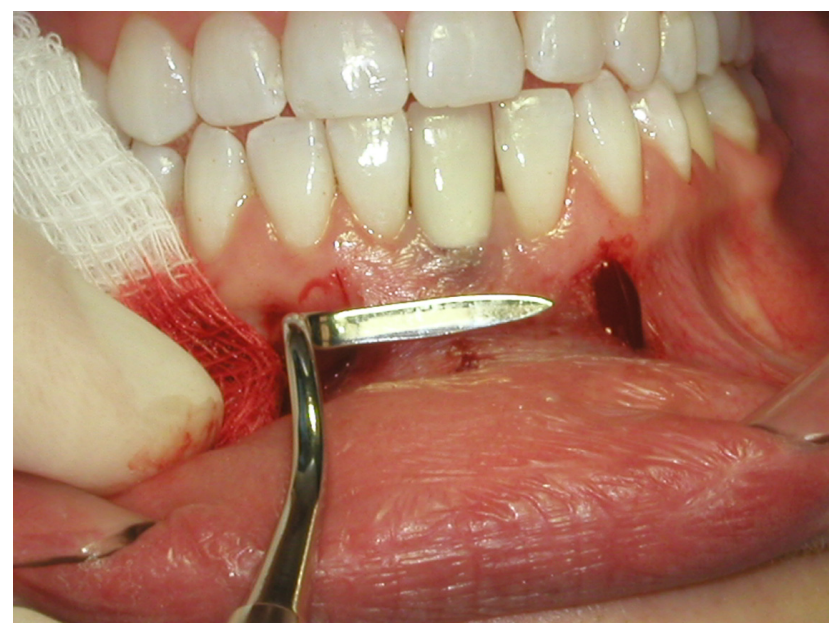

Figure 3B Partial thickness flap utilizing periodontal knife.

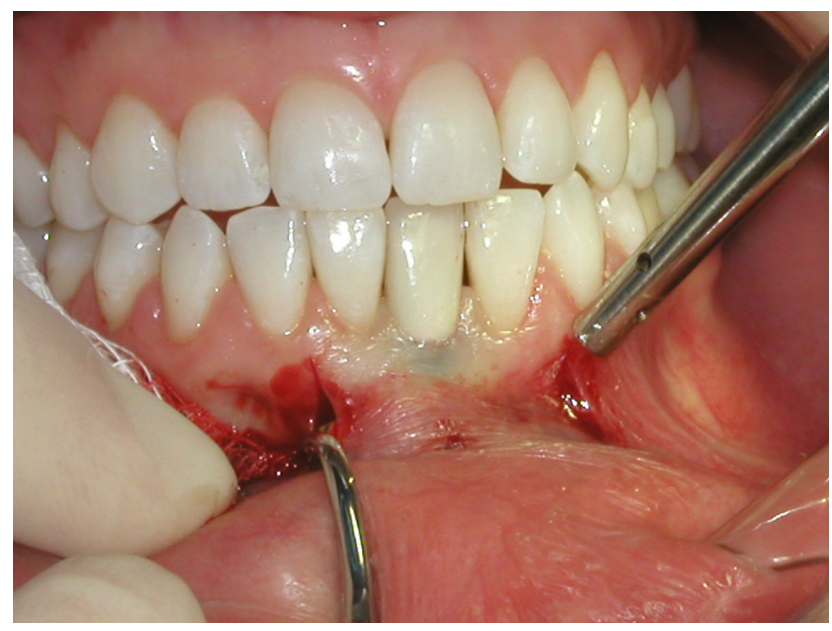

Figure 3C Releasing incisions to facilitate placement of Alloderm. 


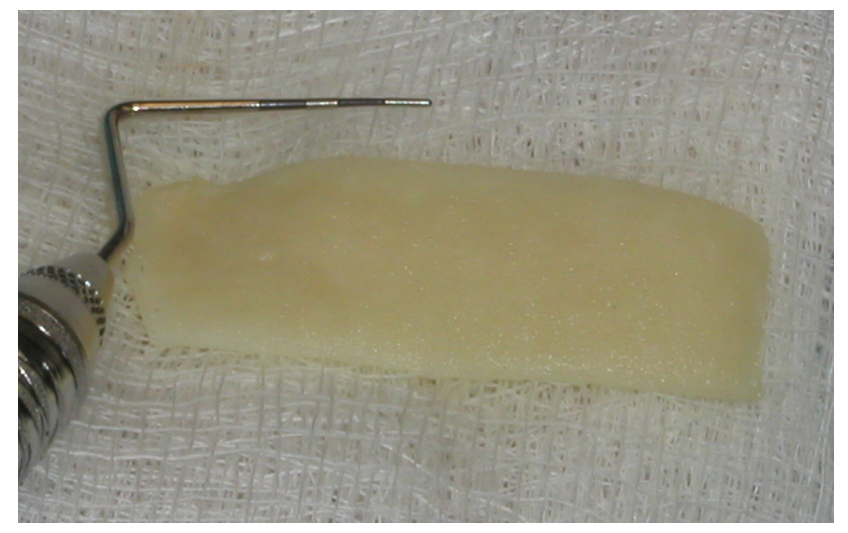

Figure 3D Alloderm material hydrated.

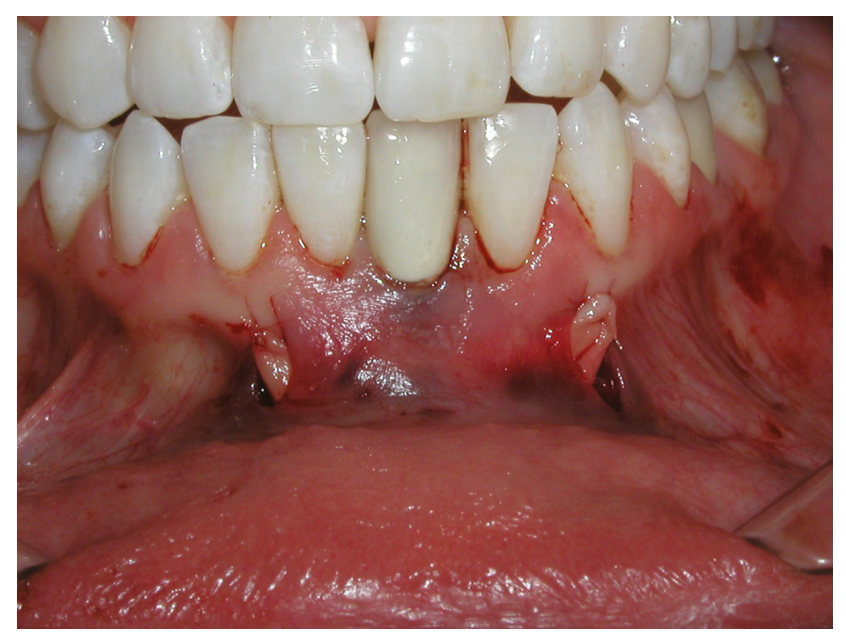

Figure 3E Alloderm sutured in place.

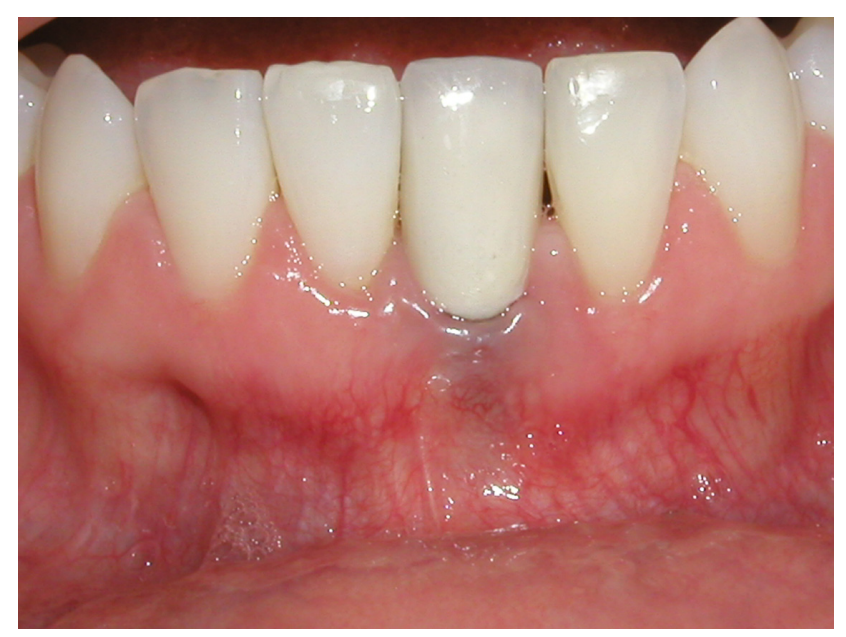

Figure 3F Nine months postoperation. reported by Lee et al ${ }^{14}$ ) that usually takes $9-12$ months to be achieved, but around dehisced dental implants, the author noticed that the phenomenon of "creeping reattachment" did not occur, mainly in my opinion, due to the lack of buccal bone and the inability of connective tissue fibers to attach to a titanium surface compared with cementum. Adverse postoperative events are usually swelling, moderate pain, and rarely hematoma or postoperative bleeding. ${ }^{15}$ The surgeries in this case report were done between 2005 and 2008 with good result. With the use of autografting and allografting materials, it was also noticed that there was an increase in the keratinized gingival tissue and the absence of scar tissue; the new gingiva blends in very well with the surrounding tissue. More studies are needed to examine and explore the possibility of soft tissue repair around dehisced dental implants.

\section{Conclusion}

The use of autogenous and allograft soft tissue material could be combined to augment the gingival tissue and improve esthetics.

\section{Disclosure}

The author report no conflicts of interest related to this case report.

\section{References}

1. Mantzikos T, Shamus I. Case report: forced eruption and implant site development. Angle Orthod. 1996;68(2):179-186.

2. Schweizer CM, Schlegel AK, Rudzki-Janson I. Endosseous dental implants in orthodontic therapy. Int Dent J. 1996;46(2):61-68.

3. Richardson G, Russell KA. Congenitally missing maxillary lateral incisors and orthodontic treatment considerations for the single tooth implant. J Can Dent Assoc. 2001;67(1):25-28.

4. Shroff B, Siegel SM, Feldman S, Siegel SC. Combined orthodontic and prosthetic therapy. Special considerations. Dent Clin North Am. 1996;40(4):911-943.

5. Langer B, Langer L. Subepithelial connective tissue graft technique for root coverage. J Periodontol. 1985;56:715-720.

6. Kassab MM, Cohen RE. Treatment of gingival recession. J Am Dent Assoc. 2002;133(11):1499-1506.

7. Kassab MM, Badawi H, Dentino AR. Treatment of gingival recession. Dent Clin North Am. 2010;54(1):129-140.

8. Miller PD. Root coverage using the free soft tissue autograft following citric acid application, part III: a successful and predictable procedure in areas of deep-wide recession. Int J Periodontics Restorative Dent. 1985;5(2):15-37.

9. Harris RJ. The connective tissue and partial thickness double pedicle graft: a predictable method of obtaining root coverage. J Periodontol. 1992;63:477-486.

10. Allen EP. AlloDerm: an effective alternative to palatal donor tissue for treatment of gingival recession. Dent Today. 2006;25(1):48, 50-52.

11. Allen AL. Use of the supraperiosteal envelope in soft tissue grafting for root coverage. I. Rationale and technique. Int J Periodontics Restorative Dent. 1994;14(3):216-227. 
12. Allen AL. Use of the supraperiosteal envelope in soft tissue grafting for root coverage. II. Clinical results. Int J Periodontics Restorative Dent 1994;14(4):302-315.

13. Goldstein M, Nasatzky E, Goultschin J, Boyan BD, Schwartz Z. Coverage of previously carious roots is as predictable a procedure as coverage of intact roots. J Periodontol. 2002;73:1419-1426.
14. Lee YM, Kim JY, Ku Y, Rhyu IN, Han SB, Choi CP. A 3-year longitudinal evaluation of subpedicle connective tissue grafts for gingival recession coverage. J Periodontol. 2002;73:1412-1418.

15. Griffin TJ, Cheung WS, Zavras AI, Damoulis PD. Postoperative complications following gingival augmentation procedures. J Periodontol. 2006;77:2070-2079.

\section{Publish your work in this journal}

Clinical, Cosmetic and Investigational Dentistry is an international, peer-reviewed, open access, online journal focusing on the latest clinical and experimental research in dentistry with specific emphasis on cosmetic interventions. Innovative developments in dental materials, techniques and devices that improve outcomes and patient satisfac- tion and preference will be highlighted. The manuscript management system is completely online and includes a very quick and fair peerreview system, which is all easy to use. Visit http://www.dovepress. com/testimonials.php to read real quotes from published authors.

Submit your manuscript here: http://www.dovepress.com/clinical-cosmetic-and-investigational-dentistry-journal 